\title{
The Art of Argumentation: A Sociolinguistic Approach to Developing Thesis Statements (The Case of Kosova High School Students)
}

\author{
Donika Elezkurtaj Bërveniku a * (D) \\ a University of Prishtina "Hasan Prishtina", Prishtina 10000, Kosova
}

Received 24 July 2017 | Received in revised form 2 October 2017 | Accepted 3 October 2017

\begin{abstract}
Living in a world of globalization, communication of various forms has become crucial. Should it be of a colloquial or formal use, language plays a vital role in our lives. As in every other area, communication is the "lifeblood" of academia as well (Becher \& Trowler, 2001). Academia cannot be separated from its discourse and could not exist without it. Therefore, argumentative discourse is of an essential nature to both scholars and students. This sociolinguistically oriented research study reports on Kosovan, high school students' problems in the process of argument building and the effectiveness of class activities that promote critical thinking and argumentation. Aiming for original and reliable results, corpus linguistics has been chosen as a means of collecting naturally occurring source corpora. The data obtained from two observed debates, 40 essay evaluations and a focus group, reveal that students are not aware of certain linguistic patterns present in spoken and/or written argumentation and that they do not feel comfortable when required to take a decision that demands systematic evaluation of their thinking in search for new answers. It is obvious from the study that in order for students to create warranted arguments, which is an inevitable skill in academia, Inquiry-based Learning should be integrated across the educational system in Kosova. The results have implications for syllabus and course materials.
\end{abstract}

(C) 2017 EJAL \& the Authors. Published by Eurasian Journal of Applied Linguistics (EJAL). This is an open-access article distributed under the terms and conditions of the Creative Commons Attribution license (CC BY-NC-ND) (http://creativecommons.org/licenses/by-nc-nd/4.0/).

Keywords: Argumentation; critical thinking; sociolinguistics; corpus; syllabus

\section{Introduction}

A teacher's decision to work towards the students' progress can be of crucial influence to the whole educational cycle. However, switching from the position of a teacher to that of a researcher can be said to be complicated. The difficulties lie in identifying the students' problems and deciding upon a method to approach them. The teacher researcher's awareness of learners' needs implies that the sociological aspect cannot be separated from the linguistic one (in the situation of argumentative discourse).

\footnotetext{
* Donika Elezkurtaj Bërveniku.

E-mail address: donikaelezkurtaj@gmail.com

http://dx.doi.org/.......
} 
By assembling a learner corpus (from both spoken and written discourse) the local researcher of this study aspired to identify learner barriers with second language argumentation and provide directions towards better acquisition of argumentation skills. The combination of spoken (debate) and written (essay assignment) analysis with learner perceptions (focus group) aim to provide original and reliable data as research results.

Academic discourse is rightly considered to be central in the world of education and research. No investigation or discovery could be made available to others lacking proper communicative transmission, which occurs both in spoken and written form. Academic discourse, much like any other kind of discourse, is only effective when users custom conventions that other members of their community find familiar and convincing (Hyland, 2009). Thus, this study would not proceed and progress without considering the following vital aspects of academic discourse: Academic Genres, Argumentative Discourse, Second Language Aspect, Study Approaches and Pedagogical Approaches.

\subsection{Academic genres}

When students begin their studies, they enter an academic community that shares certain ways of thinking, valuing and producing texts (spoken and written). Despite this, students are brought in contact with different types of texts; and being conscious of their genres will aid the understanding and interpretation of those texts. In these academic communities, there are certain commonalities among academic discourse; so core skills can and should be present (Bloor \& Bloor, 1986). Thus, Hyland (2007) states that genre is the term which is used to refer to grouping those texts together and representing how academics use language to respond to recurring situations.

Being of a community based nature and suggesting that features differ across disciplines, genre encourages scholars to research the features of the texts their correspondents need so that they become aware that when we produce academic pieces, we follow conventions for organizing messages so the correspondent can organize purpose and follow ideas. Atkinson (2003) emphasizes that theoretical interest in, especially, writing instruction shifted to a genre approach that considers discourse as a purposeful act and focuses mainly on the analysis of the contextual situation (enabling students to make sense of the world around them and to become aware of discourse as a useful and manipulatable tool (Kay \& Dudley-Evans, 1998)).

One will only be able to produce a successfully acceptable composition by taking the context of a text into account. Thus, considering the importance of academic genres, the knowledge of a language can be said to be intimately attached to a social purpose as more focus is on the correspondent's viewpoint than on that of the composer.

\subsection{Argumentative Discourse}


The key term in academic discourse is argumentation. Academic discourse is an argument itself. Argumentation is the act of forming reasons, making inductions, drawing conclusions and applying them to the case in discussion (Hyland, 2004). It can be said to be an analysis on its own. Being a carefully arranged and supported presentation of a viewpoint, it mostly leads to earning the audiences' consideration of one's perspective (Irvin, 2010).

As a mode of academic discourse, argumentation constitutes an important part of learners' academic experience. Because of the widespread presence of this genre in the academic curriculum, a common component of language classes consists of instructing argumentative speaking and writing skills (Braaksma, 2002).

The difficulties faced by language students when asked to produce a piece of text are often due to inadequate understanding of how texts are organized, which is also the case with Argumentative Essays (Swales, 1984) and Debates. As via gaining argumentation skills, students start to accept the existence of others' positions, get ready for high stakes assessments and get prepared for the real world, argumentation is said to be the number one for students in academia. As argumentation requires investigation and collection, generation and evaluation of evidence, it is thought to be one of the genres the features of which are applicable to many others (Hillocks, 2010).

\subsubsection{Spoken and written argumentation}

Being essential in academic circumstances, argumentation occurs in both spoken and written form. Debates and Argumentative essays have gained high prominence for students in academia. Considering the means of production, they obviously use two different channels (speaker-listener; writer-reader). On the other hand, what makes them similar in means of composition is their structure. Should it be preparation vise (investigating, collecting, generating and evaluating evidence) or final product vise, debates and argumentative essays follow a comparable if not identical pattern. Krieger (2005) even emphasizes the necessity of compiling an argumentative paper in preparation for a debate; hence putting forward their common features, particularly in structuring the arguments.

\subsubsection{Thesis statement}

An inevitable term when being confronted with academic and specifically argumentative discourse is the thesis statement. Aaron (1989) very briefly describes the thesis statement as the take-home message you want the reader/listener to remember. Unfortunately, this concise definition of a thesis statement is not in concord with its complexity in form and meaning.

A primary goal of academic discourse is the communication of ideas to contribute to a growing body of knowledge. Because a thesis statement clearly states what the essay is about, it guides the listener/reader through the manifestation of ideas in order to help make sense of what the speaker/writer is saying (Waddell, 2004).

Without the thesis statement, the speaker/writer will wander through incoherent thoughts and will lose the audience. Thus, the more precise the thesis statement is, 
the more organized and clear the supporting evidence will be. Requiring such a precise structure and nature, sometimes the thesis statement needs to be reorganized while the research work evolves, as the original ideas may change in the process (Karper, 2002).

\subsection{Second language aspect}

With regard to the Kosovar setting, it should be emphasized that one cannot speak of English as a first language but rather consider the factors deriving as a result of English having the featuring status of a second language.

\subsubsection{Second language acquisition and teaching}

Second Language Acquisition is a field of study which comprises a set of complex issues. When it comes to education, an important aspect is the age factor. According to many researchers, the learners' age is not only relevant in the acquisition of basic linguistic patterns but also in the acquisition of more advanced academic skills (Birdsong, 1999). It is also the adults, rather than youngsters, who seem to find it harder to understand L2 communication as a cultural process which should be compared to their own culturally based communicative behavior (Baker, 2009).

Despite students' cultural awareness, there is also linguistic awareness which speaks for understanding L1 and L2 differences in order to make correct judgments in using language (Ammar, Lightbown, \& Spada, 2010). This does not speak for constant usage of L1 in the process of L2 acquisition; but rather for L1 support in L2 acquisition (Littlewood \& Yu, 2011).

On the other hand, avoiding L1 environment and being under L2 educational medium has also proven to result in acquisition progress (Storch, 2009). All these lead to the fact that both learner characteristics and learners' conditions have a great impact in the process of second language acquisition (Lightbown \& Spada, 2006).

Despite the students' acquisition perspective, there is the teaching perspective as well. Second Language Teaching is an extremely sensitive field to be dealt with. From experience, everybody can speak of different teachers' and students' voices arguing about education. It is a well-known fact that there are certain discrepancies between these two parties' perceptions (Eslami, 2010). Nevertheless, both sides, especially the teachers, should start to understand, analyze and ideally adapt to learners' specific requirements (Bracaj, 2014). The analysis of these specific needs result in the necessity for multidisciplinary means of study - a way to enhance student engagement (Stebleton, Jensen, \& Peter, 2010).

\subsubsection{Second language speaking and writing}

The most complex skills to be acquired in second language acquisition are speaking and writing. When it comes to them, various questions arise in order to understand the areas of study: How can an utterance differ from L1 to L2? How is L2 writing different form L1 writing? Is there any sociolinguistic role in the process of L2 
acquisition? What is the role of these skills in the classroom? What is the purpose of student product in class? (Reichelt, Lefkowitz, Rinnert \& Schultz, 2012). When it comes to L2 users of English, they can be obviously distinguished from L1 users of English mainly because of lexical and structural differences between L1 and L2 (Crossley \& McNamara, 2009). Considering these differences, learners tend to use L1 during L2 production, a fact which is negatively related to L2 text quality (Weijen, Bergh, Rijlaarsdam, \& Sanders, 2009).

In the whole process of acquisition, second/foreign language context (Manchon, 2009) and forms (Cook \& Bassetti, 2005; Flowerdew, 2009) appear to be pivotal. As far as the context is concerned, focusing on the purpose of usage (Harmer, 2004) is inevitable. Speaking of forms, the priority of spoken language over written language as well as language internal contradictions should be taken into account (Kaufman \& Kaufman, 2009). Thus, the role of previous experience in both L1 and L2 is closely related to acquiring speaking and writing from learning the language itself. Despite the linguistic differences, we should also consider learners' knowledge, personality and environment as factors influencing L2 products.

\subsection{Study approaches}

What all the above mentioned share is the common interest to identify learners' existing competence in order to set a base for better acquisition. It is important to know that classroom research is not a library research. It involves people in order to improve their skills, techniques and strategies. As important it is to know why we do things, the more important it is to know what we do and how to do them better - in order to impact students positively (Ferrance, 2000). Thus, teachers need to think systematically and implement new views where improvements are possible (Burns, 2005). The attitude of inquiry a teacher-researcher should possess in order to follow a process of gathering information, analyzing and using the outcomes of analysis to take some action (Stinger, Christensen, \& Baldwin, 2009) is a leading feature towards the development in the field of acquiring academic discourse. Pedagogical research is always focused on students and understanding students' understanding. It emerges from teachers' worries. The professional knowledge gained from this research allows teachers to be autonomous researchers rather than follow prescribed traditions (Castle, 2006).

The present study draws on the research practice of Sociolinguistics with application of Corpora and consequently Discourse Analysis in order to provide a theoretically and methodologically sound framework for the examination and reflection of students' problems in the light of experience and theoretical knowledge.

The sensitive nature of this study makes the selection of research methodology extremely delicate, as well. This research project in the setting of high school education will require analysis of various perspectives. Not only will the scenario of product be investigated but that related to the student/teacher as well. This demands, of course, a complex research design which suits both settings appropriately. Starting 
from a more quantitative view and proceeding to a more qualitative one, this study will engage different approaches in order to obtain reliable and valid results.

\subsubsection{The sociolinguistic approach}

In order to have a more objective view of language (Krieger, 2003), corpora (which is a databank of naturally occurring texts) is the new term to revolutionize language learning/teaching. According to Leech (1997), corpus analysis can be illuminating in almost all branches of linguistics or language teaching. Corpus linguistics is a method which carries out linguistic analysis of systematic collections of naturally occurring texts. With systematic, Nesselhauf (2005) describes corpus as following certain extralinguistic principles of certain text types and a certain time span. Klimova (2014) sees this as a method to obtain and analyze data quantitatively and qualitatively rather than a theory of language. As language cannot be invented but only captured, using language product as evidence for the process of production is the only practical way for finding about the process in the context of language acquisition.

Thus, a particular type of corpora which represents language as produced by learners (Kennedy, 1998) is the now very prominent learner corpora. As a collection of written or spoken data produced by language learners who are acquiring a second or foreign language (McEnery \& Xiao, 2006), the results of local learner corpus can be directly integrated into the process of acquisition.

\subsubsection{Discourse analysis}

In ideal scenarios, teachers are also researchers, who support professional research and work towards solving the theory-practice problem (Elliott, 2001). It is the aim of Discourse Analysis to analyze students' spoken and written texts. It has been chosen as a consequent methodology to the initial sociolinguistically oriented corpus based research for the fact that it covers a variety of areas necessary to analyze thesis statements of both spoken and written texts.

According to Trappes-Lomax (2006) discourse analysts do what people in their everyday experience of language do instinctively and largely unconsciously: notice patterning of language in use and the circumstances (participants, situations, purposes, outcomes) with which these are typically associated.

It does the analysis of spoken and written language over and above concerns such as the structure of the clause or sentence (McCarthy, 2011). Discourse Analysis is the linguistic analysis of naturally occurring connected speech or written discourse. Roughly speaking, it refers to attempts to study the organization of language above the sentence or above the clause, and therefore to study larger linguistic units, such as conversational exchanges or written texts. It follows that discourse analysis is also concerned with language use in social contexts, and in particular with interaction or dialogue between speakers (Swann \& Ussher, 1995).

It is the particular problems or dilemmas raised by the Sociolinguistic Research which are systematically addressed by means of Discourse Analysis in order to improve an unsatisfactory state or situation. 


\subsubsection{Pedagogical approach}

Insights gained from learner corpus research have huge potential for academic discourse research. However, the overwhelming majority of corpus-based academic discourse studies are exclusively based on native corpora. Analyses of L2 learners are not absent but they tend to focus on the writing process rather than the writing product.

There are many pressures that are pulling research and teaching apart. Britten (2002), for example, states that "the twentieth century saw the university change from a site in which teaching and research stood in a reasonably comfortable relationship with each other to one in which they became mutually antagonistic" ( $p$. 157).

However, learner corpus (in contrast to other types) requires a different methodological approach which is realistic to the students' purposes, achievable to the students' abilities and acceptable by the teachers of those institutions (Hüttner, 2007). Hammond (1992) proposed a three-phased-wheel model of a teaching-learning cycle which comprises modeling, joint negotiation of text and independent construction of text. Hyland (2004) also emphasizes the advantages of this approach to teaching by naming them as being explicit, systematic, needs based, supportive, empowering, critical and conscious-rising.

Putting greater emphasis on actively engaging students and teachers with research, suitably adapted to recognize the variation and complexity of constructing knowledge in different disciplines, is one way of re-linking them in this century.

Thus, any learner-based corpus study would indirectly have indications for syllable and course material development.

\section{Identification of the research gap}

Considering the fact that the way we grasp the world is quite rooted in our culture, Kosovar students tend to fail to acquire the complexity of an issue and identify alternative/optional perspectives (Chaffee, 2006). As a result, they produce relatively deficient arguments and face large obstacles in synthesizing grasped information and evaluating/processing them. In these cases, teachers should create learning environments which intellectually challenge learners' thoughts by presenting them how to think rather than what to think (Paul \& Willsen, 1993). Students should also be brought to the point to experience the situation of changing their stand on a particular matter in response to evidence (Browne \& Keeley, 2004).

As the researcher of this study has also experienced a traditional way of learning and has been imposed how to think and act, it is crucial to work on a research that proposes to investigate and confront students' barriers in academic discourse. Encountering graduate high school students' deficiency in structuring texts, synthesizing ideas and thinking independently (providing warranted arguments) asks for investigation, confrontation and evaluation of certain data. 
The researcher's observations of students' reactions, preferences and authentic spoken and written products will be of extensive relevance to the reliable and original nature of the research and resulting data. These findings aim to contribute to the whole teaching and educational setting in Kosova and ergo actively prepare students for a critically and intellectually rich environment which shall change the approach to academic writing to a qualitative one.

Investigating and confronting students' barriers would be lacking in quality and functionality if students' attitude, teachers' standpoint or the students' writings were not studied in relation to each other. Consequently, because of numerous differences in socio-cultural, historical and educational spheres, there is constant demand for research in the field of academic discourse, particularly in the setting of Kosova.

\section{The study}

The aim of the study was to discover learners' barriers in the process of argumentation (spoken and written).

\subsection{Course background}

The English Language course is a mandatory course for all graduate students of the Sami Frasheri high school in Prishtina, Kosova. The aim of the course is to enable students to communicate more effectively in an academic context (in preparation for university studies), with a particular focus on speaking and writing. Nevertheless, the teacher uses only a particular course book for delivering classes and exercises.

\subsection{Participants' background}

The study was conducted with high school students aged 17-19. They were enrolled in a four-year high school program and were homogenous in their educational and cultural background and had no previous experience in conversing argumentatively. So far, they have studied English for eight years; their education was characterized by limited resources, large classes, obedience to authority and rote-learning.

\subsection{Data collection and procedure}

Case study data was collected through debate observation, essay analysis and a focus group.

\subsubsection{Debates}

Two debates have been conducted in two different classes respectively; which have been assigned the same argumentative topic "Should Marihuana be legalized?". The debate involved three groups in each class (the affirmative team - consisting of three students - supporting the statement, the opposing team - consisting of three students challenging the statement and the judging team - consisting of four students evaluating the evidence and arguments together with the researcher). Students were 
given one week for preparation and were finally assessed using a simple debate evaluation rubric (CSUN, 2013). After the debates had ended, an open discussion was initiated. The whole task aimed at evaluating students' oral argumentation skills.

Table 1. Debate evaluation rubric

\begin{tabular}{|c|c|c|c|c|c|}
\hline Criteria & 4 & 3 & 2 & 1 & Grade: \\
\hline $\begin{array}{l}\text { 1. Organization \& } \\
\text { Clarity: } \\
\text { Main arguments and } \\
\text { responses are outlined in } \\
\text { a clear and orderly way. }\end{array}$ & $\begin{array}{l}\text { Completely clear and } \\
\text { orderly presentation }\end{array}$ & $\begin{array}{l}\text { Mostly clear and } \\
\text { orderly in all parts }\end{array}$ & $\begin{array}{l}\text { Clear in some parts } \\
\text { but not overall }\end{array}$ & $\begin{array}{l}\text { Unclear and } \\
\text { disorganized } \\
\text { throughout }\end{array}$ & \\
\hline $\begin{array}{l}\text { 2. Use of Argument: } \\
\text { Reasons are given to } \\
\text { support the resolution }\end{array}$ & $\begin{array}{l}\text { Very strong and } \\
\text { persuasive } \\
\text { arguments given } \\
\text { throughout }\end{array}$ & $\begin{array}{l}\text { Many good } \\
\text { arguments given, } \\
\text { with only minor } \\
\text { problems }\end{array}$ & $\begin{array}{l}\text { Some decent } \\
\text { arguments, but } \\
\text { some significant } \\
\text { problems }\end{array}$ & $\begin{array}{l}\text { Few or no real } \\
\text { arguments given, or } \\
\text { all arguments given } \\
\text { had significant } \\
\text { problems }\end{array}$ & \\
\hline $\begin{array}{l}\text { 3. Use of cross- } \\
\text { examination and } \\
\text { rebuttal: } \\
\text { Identification of weakness } \\
\text { in Negative team's } \\
\text { arguments and ability to } \\
\text { defend itself against } \\
\text { attack. }\end{array}$ & $\begin{array}{l}\text { Excellent cross-exam } \\
\text { and defense against } \\
\text { Negative team's } \\
\text { objections }\end{array}$ & $\begin{array}{l}\text { Good cross-exam } \\
\text { and rebuttals, with } \\
\text { only minor slip-ups }\end{array}$ & $\begin{array}{l}\text { Decent cross-exam } \\
\text { and/or rebuttals, } \\
\text { but with some } \\
\text { significant } \\
\text { problems }\end{array}$ & $\begin{array}{l}\text { Poor cross-exam or } \\
\text { rebuttals, failure to } \\
\text { point out problems } \\
\text { in Negative team's } \\
\text { position or failure } \\
\text { to defend itself } \\
\text { against attack. }\end{array}$ & \\
\hline \multirow{2}{*}{$\begin{array}{l}\text { 4. Presentation Style: } \\
\text { Tone of voice, clarity of } \\
\text { expression, precision of } \\
\text { arguments all contribute } \\
\text { to keeping audience's } \\
\text { attention and persuading } \\
\text { them of the team's case. }\end{array}$} & $\begin{array}{l}\text { All style features } \\
\text { were used } \\
\text { convincingly }\end{array}$ & $\begin{array}{l}\text { Most style features } \\
\text { were used } \\
\text { convincingly }\end{array}$ & $\begin{array}{l}\text { Few style features } \\
\text { were used } \\
\text { convincingly }\end{array}$ & $\begin{array}{l}\text { Very few style } \\
\text { features were used, } \\
\text { none of them } \\
\text { convincingly }\end{array}$ & \\
\hline & & & & & $\begin{array}{l}\text { TOTAL } \\
\text { SCORE: }\end{array}$ \\
\hline
\end{tabular}

The groups can take a maximum of 16 and a minimum of 4 points.

\subsubsection{Essay assignment}

A week after the debate, 40 students of two classes (including the debating groups) were given a short essay assignment with the topic "Do people who commit heinous crimes deserve the death penalty?". Having in mind the examination-oriented practice at high schools in Kosova, the researcher evaluated the writings of a minimum of 250 words each after a time scale of 40 minutes given to the students. This type of assignment had been experienced several times during their studies. The essays were evaluated using a simple essay evaluation rubric. 
Table 2. Argumentative essay evaluation rubric

\begin{tabular}{|c|c|c|c|c|c|}
\hline Criteria & 4 & 3 & 2 & 1 & Grade \\
\hline $\begin{array}{l}\text { Focus \& } \\
\text { Structure }\end{array}$ & $\begin{array}{l}\text { Essay maintains a } \\
\text { clear, relevant and } \\
\text { logical organization. } \\
\text { Essay is organized into } \\
\text { multiple sections that } \\
\text { creatively and } \\
\text { intelligently build up to } \\
\text { support a unique and } \\
\text { complex argument. }\end{array}$ & $\begin{array}{l}\text { Essay maintains a clear, } \\
\text { relevant and logical } \\
\text { organization. Multiple } \\
\text { sections (groups of } \\
\text { paragraphs) work } \\
\text { together to form an } \\
\text { argument. }\end{array}$ & $\begin{array}{l}\text { Essay maintains a } \\
\text { mostly clear and } \\
\text { logical organization. } \\
\text { Simple paragraphs } \\
\text { are used (rather } \\
\text { than multiple } \\
\text { sections). }\end{array}$ & $\begin{array}{l}\text { Essay does not } \\
\text { maintain a clear } \\
\text { and logical } \\
\text { organization. } \\
\text { Simple } \\
\text { paragraphs are } \\
\text { used in a } \\
\text { disorganized } \\
\text { manner. }\end{array}$ & \\
\hline Introduction & $\begin{array}{l}\text { Introductory section } \\
\text { provides a strong } \\
\text { opening, context and a } \\
\text { complex and original } \\
\text { thesis statement. The } \\
\text { thesis includes details } \\
\text { that preview the rest of } \\
\text { the essay. }\end{array}$ & $\begin{array}{l}\text { Introductory section } \\
\text { provides a strong } \\
\text { opening, context and a } \\
\text { thesis statement. The } \\
\text { thesis includes details } \\
\text { that preview the rest of } \\
\text { the essay. }\end{array}$ & $\begin{array}{l}\text { Introductory section } \\
\text { provides a strong } \\
\text { opening, adequate } \\
\text { context and a clear } \\
\text { thesis statement. }\end{array}$ & $\begin{array}{l}\text { Introductory } \\
\text { section contains } \\
\text { some context and } \\
\text { an unclear thesis } \\
\text { statement }\end{array}$ & \\
\hline Evidence & $\begin{array}{l}\text { Student supports thesis } \\
\text { statement with } \\
\text { multiple clear and } \\
\text { relevant examples from } \\
\text { credible sources using } \\
\text { quotes and citations. } \\
\text { Evidence acknowledges } \\
\text { and refutes alternate or } \\
\text { opposing points of view } \\
\text { using quotes and } \\
\text { citations. }\end{array}$ & $\begin{array}{l}\text { Student supports thesis } \\
\text { statement with multiple } \\
\text { clear and relevant } \\
\text { examples from credible } \\
\text { sources using quotes and } \\
\text { citations. Evidence } \\
\text { acknowledges and } \\
\text { refutes alternate or } \\
\text { opposing points of view. }\end{array}$ & $\begin{array}{l}\text { Student supports } \\
\text { thesis statement } \\
\text { with some clear and } \\
\text { relevant examples } \\
\text { from credible sources } \\
\text { using quotes and } \\
\text { citations. Evidence } \\
\text { attempts to } \\
\text { acknowledge and } \\
\text { refute alternate or } \\
\text { opposing points of } \\
\text { view but does so } \\
\text { unclearly. }\end{array}$ & $\begin{array}{l}\text { Student supports } \\
\text { thesis statement } \\
\text { with few clear } \\
\text { and relevant } \\
\text { examples from } \\
\text { credible sources } \\
\text { using quotes and } \\
\text { citations. No } \\
\text { alternate points } \\
\text { are discussed. }\end{array}$ & \\
\hline Conclusion & $\begin{array}{l}\text { Essay provides a } \\
\text { concluding statement } \\
\text { that summarizes the } \\
\text { major points, explains } \\
\text { their significance, and } \\
\text { builds new ideas and } \\
\text { insights. The conclusion } \\
\text { continues to use quotes } \\
\text { and sources to support } \\
\text { its claims. }\end{array}$ & $\begin{array}{l}\text { Essay provides a } \\
\text { concluding statement } \\
\text { that summarizes the } \\
\text { major points, explains } \\
\text { their significance, and } \\
\text { builds new ideas and } \\
\text { insights. }\end{array}$ & $\begin{array}{l}\text { Essay provides } \\
\text { mostly summary and } \\
\text { explanation but } \\
\text { offers few new ideas } \\
\text { and insights. }\end{array}$ & $\begin{array}{l}\text { Essay provides } \\
\text { mostly summary } \\
\text { and offers little } \\
\text { explanation and } \\
\text { no new ideas and } \\
\text { insights. }\end{array}$ & \\
\hline Style & $\begin{array}{l}\text { Uses strong words, } \\
\text { transitional phrases } \\
\text { and complex sentences } \\
\text { throughout. } \\
\text { Grammatical } \\
\text { conventions are } \\
\text { followed successfully } \\
\text { (95\% accuracy) }\end{array}$ & $\begin{array}{l}\text { Frequently uses strong } \\
\text { words, transitional } \\
\text { phrases and complex } \\
\text { sentences. Grammatical } \\
\text { conventions are usually } \\
\text { followed with success } \\
\text { (85\% accuracy) }\end{array}$ & $\begin{array}{l}\text { Sometimes uses } \\
\text { strong words, } \\
\text { transitional phrases } \\
\text { and complex } \\
\text { sentences. } \\
\text { Grammatical } \\
\text { conventions are } \\
\text { sometimes followed } \\
\text { ( } 75 \% \text { accuracy) }\end{array}$ & $\begin{array}{l}\text { Rarely uses } \\
\text { strong words, } \\
\text { transitional } \\
\text { phrases and } \\
\text { complex } \\
\text { sentences. } \\
\text { Grammatical } \\
\text { conventions are } \\
\text { rarely followed } \\
\text { (65\% accuracy) }\end{array}$ & $\begin{array}{l}\text { TOTAL } \\
\text { SCORE: }\end{array}$ \\
\hline
\end{tabular}




\subsubsection{Focus group}

In order to gain a more detailed understanding of the students' perspective, the researcher conducted a focus group with six participants (one from each debating group). The discussion took place at a bookshop/café and lasted an hour and fifty minutes. The whole discussion was conducted in English (having some occasional switches to the students' native language, Albanian). With the participants' approval, the discussion was recorded and notes were taken. The taped discussion was transcribed verbatim where the names of the students have been changed.

\section{Findings}

The findings from the debates and essay assignments are aimed at shedding light on the students' production of ideally warranted arguments (spoken and written) thesis statements. The focus group, on the other hand, will provide insight into students' perceptions of instructional methodology they have gone through so far in their classes.

\subsection{Debates}

The debate data obtained from the twelve respondents in total (three in each debating group for two debates) regarding the usage of a thesis statement as means of providing warranted arguments is shown in Table 3.

Table 3. Student argumentation during debates

\begin{tabular}{l|ll} 
Occurrence & Explanation & Percent \\
\hline Inexistent Thesis Statement & $\begin{array}{l}\text { Information separated into different sentences rather } \\
\text { than in one statement }\end{array}$ & $70 \%$ \\
Late Thesis Statement & Essential information provided too late & $55 \%$ \\
Visible Indication & Obvious indications made & $80 \%$ \\
Obvious Fact & An obvious fact stated & $70 \%$ \\
Personal Conviction & Personal conviction used as a fact & $60 \%$ \\
Conventional Wisdom & Conventional wisdom as reason & $25 \%$ \\
Vague Vocabulary & Unacceptable word choice & $60 \%$
\end{tabular}

More than two thirds of the respondents failed to construct a thesis statement made of synthesized information and instead recalled information in separate statements. Most of the debaters used certain phrases to show that an indication for the point of the debate is being made ('The point of our position is that ...'). In half of the cases, the thesis statement got lost in time and words after being introduced too late. $70 \%$ of the students used obvious and general facts in order to support their position ('Drugs are dangerous ...'). More than half of them presented claims supporting them by personal opinions ('Relaxing with friends is wonderful...').

Conventional wisdom was applied as a reason by one fourth of the respondents ('Time cures all wounds...'). A phenomenon present throughout more than half of the debates was the use of vague vocabulary ('always', 'never', 'believe', 'need', 'feel', 'perfect'; including adverbs used as modifiers of verbs). 


\subsection{Essay assignment}

The researcher has evaluated the students' essays by using a simple essay evaluation rubric. For the sake of the research results, the findings from the essay analysis were fortunately in concord with those of the debates.

Table 4: Student argumentation in essay

\begin{tabular}{l|ll} 
Occurrence & Explanation & Percent \\
\hline Inexistent Thesis Statement & Information separated into different sentences rather than in & $45 \%$ \\
one statement & $80 \%$ \\
Visible Indication & Obvious indications made & $40 \%$ \\
Obvious Fact & Essential information provided too late & $60 \%$ \\
Personal Conviction & An obvious fact stated & $50 \%$ \\
Conventional Wisdom & Personal conviction used as a fact & $70 \%$ \\
& Unacceptable word choice & \\
& - informal & \\
& - unsophisticated & \\
& - vague & \\
& - exaggerated & \\
& - subjective & \\
Vague Vocabulary & - generally unnecessary & \\
& - generally correct & \\
& - jargon, cliché, abbreviations, slang, not gender & \\
& Information separated into different sentences rather than in & $60 \%$
\end{tabular}

Less than half of the respondents failed to construct a thesis statement made of synthesized information and instead recalled information in separate statements. 80\% of the debaters used certain phrases to show that an indication for the point of the debate is being made ('The aim of my position is that ...'). In contrast to the debates, in the essays, the late thesis statement was less distinct. Obvious facts and personal convictions also made a great part of the thesis statement construction. More evident, on the other hand, was the unacceptable word choice made by the students.

\subsection{Focus group}

The transcripts of the focus group have shown the matters below as pivotal:

- supporting a position

- critical thinking

- cultural differences

- educational traditions

- linguistic competence 


\section{Discussion}

\subsection{Supporting a position}

The biggest challenge students face when it comes to argumentation is the arguments itself; or simply saying supporting their own position. This occurrence was mostly present in the situations where students used personal convictions, conventional wisdom and vague expressions in order to make their point. It was also Kay (1998) who put forth the importance for students to make sense of the world around them rather than making account only of their own beliefs.

\subsection{Critical thinking}

This fact is closely related to the phenomenon of critical thinking. The most common cases where the lack of the ability to think critically was detected were statements with no claim and statements providing obvious facts rather than an analysis of the particular situation. Observing the debates and conducting the focus group have also seconded this problematic issue as the respondents claimed that the moment they were asked to defend an opposing position they felt 'unnatural' in doing so and thus lacked the capacity to go beyond their views.

\subsection{Cultural differences}

Being complicated in its nature, argumentative discourse becomes even more complicated when it is used as a second/foreign language. The younger the learners of the language are the easier they become acquainted to the second language community (Baker, 2009). This cultural aspect of language acquisition is an inevitable part of the competence to argument precisely in a language other than the native one. Cultural differences transmit their problems mostly via language.

\subsection{Educational traditions}

Argumentative discourse is only effective when the conversations are familiar to the community (Hyland, 2009). These familiarities can only be brought closer to students via education. Sticking only to traditional educational approaches will keep L2 students far from L1 perfection. Thus, in the case of academic discourses, genre specific and inquiry-based approaches result in triggering necessary argumentative features closer to the learner in the best way possible (Hillocks, 2010).

\subsection{Linguistic competence}

One of the most evident occurrences has derived from both debate and essay analysis, which have again proven to be closely correlated to each other in the means of argumentation (Krieger, 2005). Concerns with the correct use of vocabulary have taken a great part of structuring warranted arguments into a complete thesis 
statement. The constant need for reorganizing thesis statements (Karper, 2002) according to changing needs and views seems to be the greatest difficulty for students.

\section{Conclusion}

This study shows how important it is to consider new educational approaches when it comes to second language academic discourse. Being of a vital nature, introducing argumentative communication early in education aims for a better understanding of the world beyond the students' personal views.

The revealing form of learner corpora this study provides, combining both forms of argumentation a student can be in contact with, delivers cultural, educational and linguistic aspects to be concerned about. The fact that students are aware of these issues and their significance speaks for a positive attitude towards changes, which is a promising stance (as no change could be possible without the students' willingness to do so). Creating an environment challenging for the students and their studies definitely depends a lot on the teachers who are to refine future teaching practices and viewpoints towards academia

The study aspires to encourage teacher-researchers with similar challenges in teaching argumentative discourse to explore both learner and text perceptions so that education can better meet the learners' academic essentials.

\section{References}

Atkinson, D. (1997). A critical approach to critical thinking in TESOL. TESOL Quarterly, 31(1), 71- 94.

Ammar, A., Lightbown, P. M., \& Spada, N. (2010). Awareness of L1/L2 differences: does it matter?. Language Awareness. 19(2), 129-146.

Baker, W. (2009). Intercultural awareness and intercultural communication through English: an investigation of Thai English language users in higher education. Unpublished doctorate thesis University of Southampton.

Becher, T., \& Trowler, P. (2001). Academic tribes and territories. Philladelphia: Open University Press

Birdsong, D. (1999). Second language acquisition and the critical period hypothesis. London: Mahwah Publishers

Bloor, M., \& Bloor, T. (1986). Language for specific purposes: practice and theory. In CLCS occasional papers. Dublin: Centre for Language \& Communication Studies, Trinity College.

Braaksma, M.A.H., Rijlaarsdam, G., \& Van den Bergh, H. (2002). Observational learning and the effects of model-observer similarity. Journal of Educational Psychology, 94, 405-415.

Bracaj, M. (2014). Teaching English for specific purposes and teacher training. European Scientific Journal, 10(2), 40-49.

Britten, N., Campbell, R., Pope, C., Donovan, J., Morgan, M., \& Pill, R. (2002). Using metaethnography to synthesis qualitative research: a worked example. Journal of Health Service Research. 7, 209-15.

Browne, M. N., \& Keeley, S. M. (2004). Asking the right question. New Jersey: Pearson Prentice Hall 
Burns, A. (2005). Action research: an evolving paradigm?. Language Teaching, 38, 57-74.

Castle, K. (2006). Autonomy through pedagogical research. Teaching and Teacher Education 22, 1094-1103.

Chaffee, J. (2006). Thinking critically (8th ed.). Boston: Houghton Mifflin.

Colombo, G., Cullen, R., \& Kumaravadivelu, B. (1991). Language-learning tasks: teacher intention and learner interpretation. ELT Journal 45(2), 98-107.

Cook, V., \& Bassetti, B. (2005). Second language writing systems. Jersey: Multilingual Matters.

Crossley, S. A., McNamara, D. S. (2009). Computational assessment of lexical differences in L1 and L2 writing. Journal of Second Language Writing, 18, 119-135.

Elsami, Z. R. (2010). Teachers' voice vs. students' voice: a needs analysis approach to English for academic purposes (EAP) in Iran. English Language Teaching, 3(1), 3-11.

Elliott, J. (2001). Action research for educational change. Philadelphia: Open University Press.

Ferrance, E. (2000). Action research. Providence: Brown University.

Flowerdew, L. (2009). Using a genre-based framework to teach organizational structure in academic writing. English for Specific Purposes, 10, 370.

Hammond, J, A., Burns, H. J., Brosnan, D., \& Gerot, L. (1992). English for special purposes: A handbook for teachers of adult literacy. Sydney: NCELTR, Macquarie University.

Harmer, J. (2004). How to teach writing. USA: Pearson.

Hillocks, G. (2011). Teaching argumentative writing. Portsmouth: Heinemann

Hüttner, J. (2007). Academic writing in a foreign language: an extended genre analysis of student texts. Wien, AT, Peter Lang.

Hyland, K. (2009). Writing in the disciplines: Research evidence for specificity. Taiwan international ESP Journal, 1, 5-22.

Irvin, L. (2010). What is academic writing?. Philadelphia: OUP.

Karper, E. (2002). Writing a thesis statement. Retrieved March 23, 2004 from http://owl.english.purdue.edu/handouts/print/general/gl_thesis.html .

Kaufman, S. B., \& Kaufman, J.C. (2009). The psychology of creative writing. New York: Cambridge University Press.

Kay, H., \& Dudley- Evans, T. (1998). Genre: what teachers think. ELT Journal. 52(4) 308-314.

Kennedy, M. M. (1998). Education reform and subject matter knowledge. Journal of Research in Science Teaching, 35, 249-263.

Klimova, B. (2014). Evaluation methods as an effective tool for the development of students' learning. Procedia - Social and Behavioral Sciences, 152, 112-115.

Lightbown, P. M., \& Spada, N. (2006). How languages are learned. Oxford: OUP.

Littlewood, W., \& Yu, B. (2011). First language and target language in the foreign language classroom. Language Teaching, 44, 64-77.

Manchon, R.M. (2009). Learning, teaching and researching in writing foreign language context. Bristol: British Library Catalogue.

McCarthy, M. (2011). Discourse analysis for language teachers. London: Cambridge University Press.

McEnery, T., Xiao, R., \& Tono, Y. (2006). Corpus-based language studies: an advanced resource book. London/New York: Routledge.

Nesselhauf, N. (2004). How learner corpus analysis can contribute to language teaching: A study of support verb constructions. Aston/Bernardini/Stewart, 109-124.

Paul, R., \& Willsen, A. (1993). Frameworks of thinking. London: Oxford University Press. 
Reichelt, M., Lefkowiz, N., Rinnert, C., \& Schulz, J. M. (2012). Key issues in foreign language writing. Foreign Language Annals, 45(1), 22-41.

Stebleton, M., Jensen, M., \& Peter, G. (2010). Enhancing student engagement in a multidisciplinary, first-year experience course. College Teaching Methods and Styles, 1, 1-5.

Storch, N. (2009). The impact of studying in a second language (L2) medium university on the development of L2 writing. Journal of Second Language Writing, 18, 103-118.

Stringer, E. (2004). Action research in education. London: Routledge.

Swales, J. M., \& Feak, C. B. (1994). Academic writing for graduate students. Oxford: Oxford University Press.

Swann, C. J., \& Ussher, J. M. (1995). A discourse analytic approach to women's experience of premenstrual syndrome. Journal of Mental Health, 4, 359-367.

Trappes-Lomax, H. (2006). Discourse analysis. In A. Davies \& C. Elder (Eds.), The handbook of applied linguistics (p. 133-164). Malden: Blackwell Publishing.

Waddell, C. Thesis writing. Retrieved March 23, 2004 from http://www.rpi.edu/web/writingcen ter/thesis.html.

Weijen, D. van, Berg, H. van den, Rijlaarsdam, G., \& Sanders, Ted. (2009). L1 use during L2 writing: An empirical study of a complex phenomenon". Journal of Second Language Writing, 18, 235-250.

\section{Copyrights}

Copyright for this article is retained by the author(s), with first publication rights granted to the Journal.

This is an open-access article distributed under the terms and conditions of the Creative Commons Attribution license (CC BY-NC-ND) (http://creativecommons.org/licenses/by-nc-nd/4.0/). 